\title{
Association between TP53 gene deletion and protein expression in esophageal squamous cell carcinoma and its prognostic significance
}

\author{
MADINIYET NIYAZ ${ }^{1}$, JULAITI AINIWAER ${ }^{2}$, ABULAJIANG ABUDUREHEMAN $^{2}$, LIWEI ZHANG $^{2}$, \\ ILYAR SHEYHIDIN $^{2}$, ABDUHENY TURHONG $^{2}$, REN CAI $^{1}$, ZHICHAO HOU $^{2}$ and EDRIS AWUT ${ }^{2}$ \\ ${ }^{1}$ Clinical Medicine Research Institute; ${ }^{2}$ Department of Thoracic Surgery, \\ The First Affiliated Hospital of Xinjiang Medical University, Urumqi, Xinjiang 830054, P.R. China
}

Received June 24, 2019; Accepted April 20, 2020

DOI: $10.3892 / \mathrm{ol} .2020 .11709$

\begin{abstract}
The aim of the present study was to investigate the association between tumor protein 53 (TP53) gene deletion and protein expression and clinical features in esophageal squamous cell carcinoma (ESCC), and to evaluate the predictive value of these two characteristics in the prognosis of ESCC. Immunohistochemistry (IHC) and fluorescence in situ hybridization (FISH) were performed to detect the expression of p53 protein and gene deletion in ESCC tissue samples from different ethnic groups in Xinjiang, in order to analyze their association with clinicopathological characteristics and patient prognosis, as well as the sensitivity and specificity of the two methods. In addition, the results were further validated by tissue microarray from a different region. The positive rate of p53 protein expression was $54.5 \%$ (201/369) in the multi-ethnic group, and was significantly different between sex $(\mathrm{P}=0.026)$ and between tumor differentiation groups $(\mathrm{P}=0.032)$. FISH demonstrated that the TP53 gene deletion rate was $31.8 \%(68 / 214)$, which was significantly different between different tumor differentiation $(\mathrm{P}=0.002)$, lymph node metastasis $(\mathrm{P}=0.005)$ and vascular invasion $(\mathrm{P}<0.001)$ groups. The survival rate of patients with TP53 gene deletion was significantly lower than those without TP53 gene deletion $(\mathrm{P}<0.05)$. The positive rate of $\mathrm{p} 53$ protein expression in the tissue microarray was $58.1 \%$ (68/117), which was significantly different between the depth of invasion groups $(\mathrm{P}=0.011)$. The TP53 gene deletion rate was $47.9 \%$ (56/117), which significantly differed according to lymph node metastasis $(\mathrm{P}=0.003)$ and
\end{abstract}

Correspondence to: Professor Edris Awut, Department of Thoracic Surgery, The First Affiliated Hospital of Xinjiang Medical University, 137 Liyushan South Road, Urumqi, Xinjiang 830054, P.R. China

E-mail: 15999180777@qq.com

Key words: esophageal squamous cell carcinoma, tumor protein 53, deletion, fluorescence in situ hybridization, immunohistochemistry, prognosis
TNM stage $(\mathrm{P}=0.01)$. In addition, the total concordance rates of the two methods were 60.3 and $64.1 \%$, respectively. There were also significant differences in the positive rate of TP53 gene deletion and protein expression in different stages of ESCC $(\mathrm{P}<0.05)$, which increased gradually with the progression of ESCC. The deletion of the TP53 gene in esophageal cancer was associated with poor prognosis and may be an important biomarker for evaluating the prognosis of patients with ESCC. The combination of FISH and IHC methods could significantly improve the detection rate of TP53 gene abnormalities and the accuracy of prognostic assessment of ESCC.

\section{Introduction}

Esophageal cancer is one of the most common malignant tumors. It is associated with high mortality rates and is the sixth leading cause of cancer-related death in the world $(1,2)$. China has a high incidence of esophageal cancer and the highest morbidity and mortality rates in the world. Approximately one-half of new cases each year are recorded in China, and the majority is squamous cell carcinoma (3-5). The incidence of esophageal cancer exhibits significant regional and ethnic differences (6). Despite great progress in the diagnosis and treatment of esophageal cancer, the 5-year survival rate is still poor (7). Therefore, identifying biomarkers related to the occurrence, development and prognosis of esophageal cancer is important for early diagnosis and treatment, as well as for finding new targets and treatment methods.

Tumor protein 53 (TP53) is a recognized tumor suppressor gene located on chromosome 17q13.1. The TP53 gene plays an important role in regulating the cell cycle, apoptosis and DNA damage repair $(8,9)$. Wild-type TP53 can inhibit the cell cycle and activate apoptosis-related genes that induce apoptosis and regulate cell proliferation (10). Mutations in TP53 can lead to the loss of these functions, inducing uncontrolled cell growth and the promotion of tumor development $(11,12)$. These TP53 abnormalities may lead to DNA damage and subsequent aneuploidy.

The TP53 gene mutation is the most common gene alteration in many tumors, including esophageal cancer. It also plays an important role in the occurrence and development of esophageal 
cancer $(13,14)$. Although the biological significance of TP53 gene mutation is well characterized, its clinical significance in esophageal cancer remains controversial, especially as a prognostic biomarker. Previous studies demonstrated that p53 was highly expressed in esophageal cancer tissue and was associated with tumor malignancy (15-17). However, other previous studies reported that the expression of p53 protein had no significant association with the prognosis of esophageal cancer $(18,19)$. The detection of mutant $\mathrm{p} 53$ protein by immunohistochemistry (IHC) has some limitations. For example, viral infection, stress and the regulation of other proteins can also change the aggregation of $\mathrm{p} 53$ protein (20). Therefore, the overexpression of $\mathrm{p} 53$ does not always indicate a mutation in the TP53 gene. Similarly, TP53 mutation does not always lead to the accumulation of p53 protein in cells. This characteristic of the TP53 gene limits the use of IHC in TP53 gene research, which may be the cause of the conflicting results in the study of TP53 in esophageal cancer.

Fluorescence in situ hybridization (FISH) is a molecular pathological method with high sensitivity and specificity, which uses specific DNA probes to detect chromosomal aberrations, as well as gene deletion and amplification $(21,22)$. It has been reported that deletion of the TP53 gene plays an important role in the occurrence and development of esophageal cancer $(23,24)$. At present, to the best of the authors' knowledge, associations between the IHC and FISH methods in the detection of TP53 in multi-ethnic esophageal cancer have not been reported.

In the present study, IHC and FISH were used to analyze the role of TP53 in the occurrence, development and adverse prognosis of esophageal cancer in different ethnic groups in Xinjiang (multi-ethnic group). In addition, a tissue microarray (TMA) group from different regions (including other high-incidence areas in China, where the etiology of esophageal cancer is different from Xinjiang province owing to the difference of diet and living habits) was used to validate the results. The complementarity, clinical practicability and the accuracy of the detection of TP53 abnormality in esophageal cancer using these two methods were evaluated.

\section{Patients and methods}

Patients and samples. A total of 369 paraffin-embedded esophageal squamous cell carcinoma (ESCC) and 187 matched adjacent normal tissue specimens from patients of Kazakh, Uygur and Han ethnicities, who underwent radical surgery between January 2012 and December 2014 in The Thoracic Surgery Department of The First Affiliated Hospital of Xinjiang Medical University were collected. Glass slides with $4-\mu \mathrm{m}$ tissue sections were produced from the paraffin-embedded blocks for IHC and FISH detection. Among the 369 patients, 257 were male and 112 were female, with an average age of 60.8 years (range, $37-83$ years). With regards to differentiation, 77 cases were poorly differentiated, 196 cases were moderately differentiated and 96 cases were highly differentiated. Lymph node metastasis was detected in 158 cases, while 211 cases exhibited no lymph node metastasis. With regards to TNM stage (25), there were 30 cases with stage I, 119 cases with stage II and 220 cases with stage III. None of the patients had received radiotherapy, chemotherapy or any other cancer treatment before surgery. Complete follow-up data were available for 214 patients. The survival time was measured from the date of surgery to death or the last follow-up date. All experiments were approved by The Ethics Committee of The First Affiliated Hospital of Xinjiang Medical University, and written informed consent was obtained from all participants.

TMA was carried out by Shanghai Core Super Biotechnology Co., Ltd. There were 117 cases of ESCC with one core (diameter, $1.5 \mathrm{~mm}$ ) for each tumor sample, including 87 males and 30 females, with an average age of 64.7 years (range, 39-82 years). With regards to differentiation, 32 were poorly differentiated, 59 were moderately differentiated and 26 were highly differentiated. There were 63 cases of lymph node metastasis. Furthermore, there were 7 cases with stage I, 49 cases with stage II, 57 cases with stage III and 4 cases with stage IV. The patients received radical surgery between January 2006 and October 2008, and complete follow-up data were available for 100 patients. The follow-up period was terminated in September 2019 and the total follow-up time was 5.8-7.8 years. In addition, 3 normal esophageal mucosa tissues, 97 adjacent normal tissues, 13 precancerous lesions and 9 metastatic lesions of ESCC were included in the TMA.

$I H C$. Tumor samples were fixed with $10 \%$ neutral formalin for $12 \mathrm{~h}$ in room temperature, then replaced with new $10 \%$ neutral formalin for $24 \mathrm{~h}$, embedded in paraffin, and sectioned into $4-\mu \mathrm{m}$-thick slices. IHC was performed as previously described (15). In brief, the tissue sections were incubated at $60^{\circ} \mathrm{C}$ for $1 \mathrm{~h}$, then dewaxed and hydrated in xylol and gradient alcohol, and placed in 3\% hydrogen peroxide solution for $10 \mathrm{~min}$ to remove endogenous peroxidase. The antigen retrieval step was performed by heating in a microwave oven at $95^{\circ} \mathrm{C}$ for $10 \mathrm{~min}$ in citrate buffer $(\mathrm{pH} \mathrm{7.0)}$ ). After cooling at room temperature, the sections were treated with mouse anti-human p53 monoclonal antibody (1:400; P 5813, Sigma-Aldrich; Merck KGaA) and incubated at $4^{\circ} \mathrm{C}$ overnight in a moist chamber. The sections were then treated with universal secondary antibody (ready to use, PV-6000, Beijing Zhongshan Jinqiao Biotechnology Co., Ltd) and incubated at $37^{\circ} \mathrm{C}$ for $25 \mathrm{~min}$. Finally, DAB and hematoxylin were used to visualize immunoreactivity and for counterstaining, respectively. Both steps were performed at room temperature for $3 \mathrm{~min}$. Retrospective tissue sections of confirmed breast cancer were provided by the Department of Pathology (The First Affiliated Hospital of Xinjiang Medical University) were used as the positive control. Informed consent was provided by patients at the time of tissue collection. PBS was used as the negative control instead of primary antibody.

The results were independently evaluated by two pathologists in a blind manner. A total of five high-power fields of vision (magnification, $x 20$ ) were observed under a light microscope (Leica DM 3000B; Lecia Microsystems $\mathrm{GmbH}$ ) on each slide and 100 tumor cells were counted in each field, and the percentage of positive cells were calculated. Primary lesions with evident nuclear staining in $>10 \%$ tumor cells, including the basal cell layer of the mucosa that had corresponding p53 characteristic positive staining, was determined as positive. Weak staining limited to basal cells was considered to be negative (26).

FISH. FISH was performed using a mixture of red-labeled TP53 and green-labeled chromosome 17 centromere control 

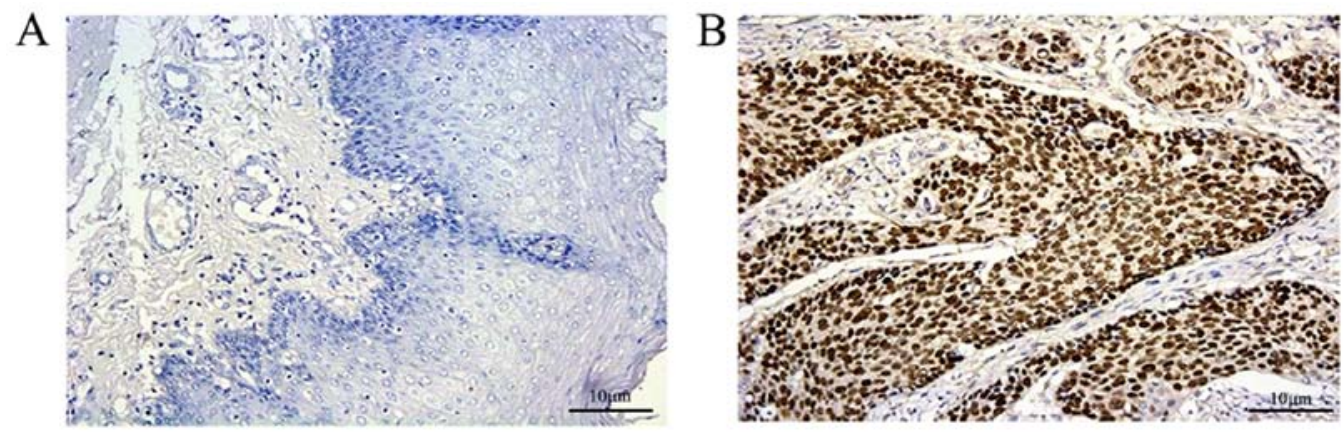

Figure 1. p53 protein expression by immunohistochemistry. (A) Adjacent normal tissue. (B) Esophageal squamous cell carcinoma tissue. Magnification, x10.

probe (Cytocell Ltd.). The amount of p53 probe is $40-50 \mathrm{ng} / \mathrm{test}$ and $159 \mathrm{~kb}$ in length covers the whole TP53 gene, and amount of control probe is 60-75 $\mathrm{ng} / \mathrm{test}$, respectively. Briefly, tissue samples were incubated at $60^{\circ} \mathrm{C}$ for $2 \mathrm{~h}$, then dewaxed with xylol, hydrated with gradient ethanol solution, and washed with ultra-pure water. The slides were then incubated at $80^{\circ} \mathrm{C}$ in Vysis pretreatment solution (Vysis, Inc.; Abbot Pharmaceutical, Co., Ltd.) for $15 \mathrm{~min}$. After washing with ultra-pure water, the slides were incubated in Vysis protease I solution (Vysis, Inc.; Abbot Pharmaceutical, Co., Ltd.) at $37^{\circ} \mathrm{C}$ for $10 \mathrm{~min}$, and then dehydrated in a series of cold ethanol solutions $(70,80,90$ and $100 \%$, each for $2 \mathrm{~min}$ ) after washing with ultra-pure water. Following this, $10 \mu \mathrm{l}$ of the hybrid mixture was added and the glass slides were covered with rubber cement. Slides were then denatured at $75^{\circ} \mathrm{C}$ for $5 \mathrm{~min}$ and hybridized at $37^{\circ} \mathrm{C}$ overnight, using a hybridization instrument. The next day, the slides were washed with 2X SSC (ID Labs ${ }^{\mathrm{TM}}$ Inc. Biotechnology, https://www.lookbio.com/) solution for $2 \mathrm{~min}$ at $72^{\circ} \mathrm{C}$, then at room temperature for $1 \mathrm{~min}$. Subsequently, $5 \mu \mathrm{l}$ DAPI was applied to each spot and covered with a cover slip. A confocal laser scanning microscope (Leica Microsystems $\mathrm{GmbH}$, magnification, $\mathrm{x} 100$ ) was used for imaging and analysis. The length of stimulated luminescence were: Blue (DAPI) $405 \mathrm{~nm}$, green (FITC) $488 \mathrm{~nm}$, red (Texas Red) $561 \mathrm{~nm}$, respectively.

For analysis, $\geq 100$ non-overlapping and complete nuclei with fluorescent signals were counted, and the results were calculated according to the percentage of nuclei with signal changes. There are two red and two green signals in normal nuclei. Samples with $>30 \%$ of tumor nuclei with either none or only one red signal per probe were determined to indicate TP53 deletion.

Statistical analysis. Data were analyzed using SPSS 20.0 software (IBM Corp.). The $\chi^{2}$ test and Fisher's exact test were conducted. Survival analysis was performed using Kaplan-Meier and log-rank tests. Univariate and multivariate analyses were conducted by $\mathrm{Cox}$ regression. $\mathrm{P}<0.05$ was considered to indicate a statistically significant difference.

\section{Results}

Association of p53 protein expression with clinicopathological factors. The positive expression rates of p53 protein in cancer tissue and adjacent normal tissue were $54.5 \%$ (201/369) and $1.1 \%(2 / 187)$, respectively, and this difference was statistically significant $(\mathrm{P}<0.001$; Fig. 1; Table I). The expression of $\mathrm{p} 53$ protein was significantly associated with $\operatorname{sex}(\mathrm{P}=0.026)$ and tumor differentiation $(\mathrm{P}=0.032)$. There were no significant associations between $\mathrm{p} 53$ expression and age, TNM stage, lymph node metastasis ( $\mathrm{N}$ classification), depth of invasion ( $\mathrm{T}$ classification) or vascular invasion. In addition, the expression rates of p53 in ESCC of the Kazakh, Uygur and Han ethnic groups were 56.3, 53.6 and $53.7 \%$, respectively. There was no significant difference in the expression of $\mathrm{p} 53$ protein among the different ethnicities ( $\mathrm{P}>0.05$; data not shown).

In the TMA analysis, the positive expression rate of p53 protein was 58.1\% (68/117) in cancer tissues and 11.3\% (11/97) in adjacent normal tissues. This difference was statistically significant $(\mathrm{P}<0.001)$. There was a significant association between $\mathrm{p} 53$ protein expression and the depth of invasion $(\mathrm{P}=0.011$; Table II), but there was no significant difference in 553 protein expression between other clinicopathological factors, such as sex, age, TNM stage and lymph node metastasis (Table II).

TP53 gene deletion and its associations with clinicopathological factors. FISH was performed in 214 of the 369 patients with complete follow-up data. The deletion rates of the TP53 gene were $31.8 \%$ (68/214) in cancer tissue and $8.3 \%(2 / 24)$ in adjacent normal tissue, and the difference was statistically significant ( $\mathrm{P}=0.01$; Fig. 2; Table III). Among these, the TP53 deletion rates in Kazakh, Uygur and Han ethic groups were $31.0,36.1$ and $28.2 \%$, respectively; there was no significant difference when comparing the different ethnic groups ( $P>0.05$, data not shown). TP53 gene deletion was significantly associated with tumor differentiation $(\mathrm{P}=0.002)$, lymph node metastasis $(\mathrm{P}=0.005)$ and vascular invasion $(\mathrm{P}<0.001$; Table III $)$. There were no significant associations between TP53 gene deletion and other clinicopathological factors $(\mathrm{P}>0.05)$.

In the TMA analysis, the deletion rates of the TP53 gene were $47.9 \%(56 / 117)$ in cancer tissues and $2.1 \%(2 / 97)$ in adjacent normal tissues $(\mathrm{P}<0.001)$. TP53 gene deletion was significantly associated with lymph node metastasis $(\mathrm{P}=0.003)$ and TNM stage $(\mathrm{P}=0.01)$. However, there was no significant difference in TP53 gene deletion between other clinicopathological factors ( $\mathrm{P}>0.05$; Table IV).

Association between TP53 gene abnormalities and prognosis. Kaplan-Meier survival analysis was used to further analyze the relationship between TP53 gene abnormalities 
Table I. Association between p53 expression and clinicopathological characteristics of patients with ESCC.

\begin{tabular}{|c|c|c|c|c|c|}
\hline \multirow[b]{2}{*}{ Characteristics } & \multirow[b]{2}{*}{$\mathrm{n}$} & \multicolumn{2}{|c|}{ p53 expression } & \multirow[b]{2}{*}{$\chi^{2}$} & \multirow[b]{2}{*}{ P-value } \\
\hline & & Positive, $\mathrm{n}(\%)$ & Negative, n (\%) & & \\
\hline Specimen & & & & 152.682 & $<0.001$ \\
\hline Adjacent normal tissue & 187 & $2(1.1)$ & $185(98.9)$ & & \\
\hline ESCC & 369 & $201(54.5)$ & $168(45.5)$ & & \\
\hline $\operatorname{Sex}$ & & & & 4.179 & 0.026 \\
\hline Female & 112 & $70(62.5)$ & $42(37.5)$ & & \\
\hline Male & 257 & $131(51.0)$ & $126(49.0)$ & & \\
\hline Age, years & & & & 1.658 & 0.119 \\
\hline$>65$ & 145 & $85(58.6)$ & $60(41.4)$ & & \\
\hline$\leq 65$ & 224 & $116(51.8)$ & $108(48.2)$ & & \\
\hline TNM stage & & & & 0.615 & 0.450 \\
\hline I-II & 232 & $130(56.0)$ & $102(44.0)$ & & \\
\hline III & 137 & $71(51.8)$ & $66(48.2)$ & & \\
\hline T classification & & & & 0.739 & 0.226 \\
\hline $\mathrm{T} 1-\mathrm{T} 2$ & 145 & $83(57.2)$ & $62(42.8)$ & & \\
\hline T3-T4 & 224 & $118(52.7)$ & $106(47.3)$ & & \\
\hline $\mathrm{N}$ classification & & & & 1.642 & 0.120 \\
\hline No & 211 & $121(57.3)$ & 90 (42.7) & & \\
\hline Yes & 158 & $80(50.6)$ & $78(49.4)$ & & \\
\hline Differentiation & & & & 3.904 & 0.032 \\
\hline Good & 96 & $44(45.8)$ & $52(54.2)$ & & \\
\hline Moderate-poor & 273 & $157(57.5)$ & $116(42.2)$ & & \\
\hline Tumor size & & & & 3.484 & 0.074 \\
\hline$<4$ & 204 & $120(58.8)$ & $84(41.2)$ & & \\
\hline$\geq 4$ & 165 & $81(49.1)$ & $84(50.9)$ & & \\
\hline Vascular invasion & & & & 0.049 & 0.893 \\
\hline Negative & 294 & $161(54.8)$ & $133(45.2)$ & & \\
\hline Positive & 75 & $40(53.3)$ & $35(45.7)$ & & \\
\hline
\end{tabular}

ESCC, esophageal squamous cell carcinoma.

and ESCC prognosis. There were no significant associations between p53 protein expression and the overall survival of patients with ESCC (P>0.05, data not shown). However, TP53 gene deletion was negatively associated with overall survival. Patients with TP53 gene deletion had a worse prognosis $(\mathrm{P}<0.05$; Fig. 3A). In addition, univariate Cox regression analysis demonstrated that TP53 gene deletion, lymph node metastasis and vascular invasion were significantly associated with the overall survival of patients with $\operatorname{ESCC~}(\mathrm{P}<0.05$; Table V). Multivariate Cox analysis demonstrated that lymph node metastasis and vascular invasion were independent prognostic factors for ESCC.

In the TMA group, Kaplan-Meier analysis demonstrated that both p53 protein expression and TP53 gene deletion were not associated with the overall survival of patients with ESCC. However, patients with the TP53 gene deletion had a worse prognosis than those without the deletion (Fig. 3B). In addition, univariate Cox regression analysis showed that the depth of invasion, lymph node metastasis and tumor differentiation were significantly associated with overall survival ( $\mathrm{P}<0.05$; Table VI). Furthermore, multivariate Cox analysis suggested that the depth of invasion and tumor differentiation were independent prognostic factors, patients with deeper invasion and lower differentiation had a worse prognosis.

Concordance between the results of IHC and FISH. The $\chi^{2}$ test suggested that there was a significant association between the results of IHC and FISH $(\mathrm{P}=0.007)$. The positive concordance rate between IHC and FISH was 41.1\% (39/95), the negative concordance rate was $75.6 \%(90 / 119)$, and the total concordance rate was $60.3 \%$ (129/214). There was also a significant association between IHC and FISH in the TMA analysis $(\mathrm{P}=0.001)$. The positive concordance rate of IHC and FISH was $60.3 \%$ (41/68), while the negative concordance rate was $69.4 \%(34 / 49)$, and the total concordance rate was $64.1 \%$ (75/117; Table VII).

The present study also analyzed TP53 gene deletion and protein expression in different stages of esophageal cancer 
Table II. Association between p53 expression and clinicopathological characteristics of patients with ESCC (tissue microarray).

\begin{tabular}{|c|c|c|c|c|c|}
\hline \multirow[b]{2}{*}{ Characteristics } & \multirow[b]{2}{*}{$\mathrm{N}$} & \multicolumn{2}{|c|}{ p53 expression, IHC } & \multirow[b]{2}{*}{$\chi^{2}$} & \multirow[b]{2}{*}{ P-value } \\
\hline & & Positive, n (\%) & Negative, n (\%) & & \\
\hline Specimen & & & & 49.833 & $<0.001$ \\
\hline Adjacent normal tissue & 97 & $11(11.3)$ & $86(88.7)$ & & \\
\hline ESCC & 117 & $68(58.1)$ & $49(41.9)$ & & \\
\hline Sex & & & & 0.035 & 0.509 \\
\hline Female & 30 & $17(56.7)$ & $13(43.3)$ & & \\
\hline Male & 87 & $51(58.6)$ & $36(41.4)$ & & \\
\hline Age, years & & & & 0.106 & 0.447 \\
\hline$>60$ & 76 & $45(59.2)$ & $31(40.8)$ & & \\
\hline$\leq 60$ & 41 & $23(56.1)$ & $18(43.9)$ & & \\
\hline TNM stage & & & & 0.337 & 0.347 \\
\hline I-II & 56 & $31(55.4)$ & $25(44.6)$ & & \\
\hline III-IV & 61 & $37(60.7)$ & $24(39.3)$ & & \\
\hline T classification & & & & 6.405 & 0.011 \\
\hline $\mathrm{T} 1-\mathrm{T} 2$ & 23 & $8(34.8)$ & $15(65.2)$ & & \\
\hline T3-T4 & 94 & $60(63.8)$ & $34(36.2)$ & & \\
\hline $\mathrm{N}$ classification & & & & 0.054 & 0.483 \\
\hline No & 54 & $32(59.3)$ & $22(40.7)$ & & \\
\hline Yes & 63 & $36(57.1)$ & $27(42.6)$ & & \\
\hline Differentiation & & & & 0.96 & 0.567 \\
\hline Good & 26 & $15(57.7)$ & $11(42.3)$ & & \\
\hline Moderate-poor & 91 & $53(58.2)$ & $38(41.8)$ & & \\
\hline
\end{tabular}

ESCC, esophageal squamous cell carcinoma; IHC, immunohistochemistry.
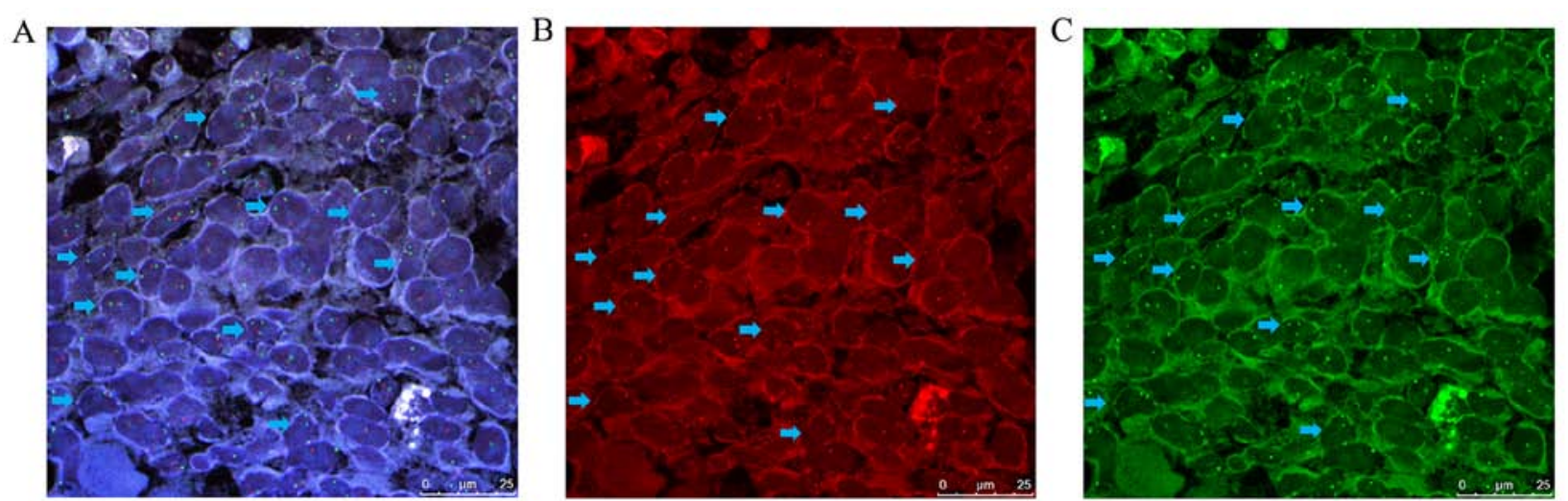

Figure 2. Representative results of esophageal cancer samples detected using FISH showing TP53 gene deletion (laser confocal). (A) Overlay, (B) TP53 signal and (C) chromosome 17 centromere signals. Blue arrows refer to the cells with TP53 gene deletion. Magnification, x100. TP53, tumor protein 53; FISH, fluorescence in situ hybridization.

(Fig. 4). The positive rates of TP53 gene deletion in normal esophageal mucosa, adjacent normal tissues, precancerous lesions, ESCC tissues and metastatic lesions of esophageal cancer were $0 \%(0 / 3), 2.1 \%(2 / 97), 30.8 \%(4 / 13), 47.9 \%(56 / 117)$ and $88.9 \%(8 / 9)$, respectively. The positive expression rates of p53 protein in these tissues were $0 \%(0 / 3), 11.3 \%$ (11/97), $46.2 \%$ (6/13), 58.1\% (68/117) and 77.8\% (7/9), respectively. There were significant differences in TP53 gene deletion and protein expression when comparing the different histological stages $(\mathrm{P}<0.05$; Table VIII).

\section{Discussion}

Mutations in $\mathrm{p} 53$ protein are carcinogenic and can promote the invasion, metastasis, proliferation and survival of tumors (27). The accumulation of p53 protein may indicate TP53 gene 
Table III. Association between p53 gene deletion and clinicopathological characteristics of patients with ESCC.

\begin{tabular}{|c|c|c|c|c|}
\hline \multirow[b]{2}{*}{ Characteristics } & \multicolumn{2}{|c|}{ p53 FISH } & \multirow[b]{2}{*}{$\chi^{2}$} & \multirow[b]{2}{*}{ P-value } \\
\hline & Positive, n (\%) & Negative, n (\%) & & \\
\hline Specimen & & & 5.712 & 0.01 \\
\hline Adjacent normal tissue & $2(8.3)$ & $22(91.7)$ & & \\
\hline ESCC & $68(31.8)$ & $146(68.2)$ & & \\
\hline Sex & & & 0.051 & 0.872 \\
\hline Female & $19(30.6)$ & $43(69.4)$ & & \\
\hline Male & $49(32.2)$ & $103(67.8)$ & & \\
\hline Age, years & & & 1.653 & 0.224 \\
\hline$>60$ & $29(37.2)$ & $49(62.8)$ & & \\
\hline$\leq 60$ & 39 (28.7) & $97(71.3)$ & & \\
\hline TNM stage & & & 3.23 & 0.089 \\
\hline I-II & $39(27.7)$ & $102(72.3)$ & & \\
\hline III & $29(39.7)$ & $44(60.3)$ & & \\
\hline $\mathrm{T}$ classification & & & 0.043 & 0.881 \\
\hline $\mathrm{T} 1-\mathrm{T} 2$ & $26(31.0)$ & $58(69.0)$ & & \\
\hline T3-T4 & $42(32.3)$ & $88(67.7)$ & & \\
\hline $\mathrm{N}$ classification & & & 7.278 & 0.005 \\
\hline No & $30(24.4)$ & 93 (75.6) & & \\
\hline Yes & $38(41.8)$ & $53(58.2)$ & & \\
\hline Differentiation & & & 8.963 & 0.002 \\
\hline Good & $11(17.2)$ & $53(82.8)$ & & \\
\hline Moderate-Poor & $57(38.0)$ & $93(62.0)$ & & \\
\hline Tumor size & & & 0.273 & 0.66 \\
\hline$<4$ & $38(33.3)$ & $76(66.7)$ & & \\
\hline$\geq 4$ & $30(30.0)$ & $70(70.0)$ & & \\
\hline Vascular invasion & & & 16.274 & $<0.001$ \\
\hline Negative & $45(25.7)$ & $130(74.3)$ & & \\
\hline Positive & $23(59.0)$ & $16(41.0)$ & & \\
\hline
\end{tabular}

ESCC, esophageal squamous cell carcinoma
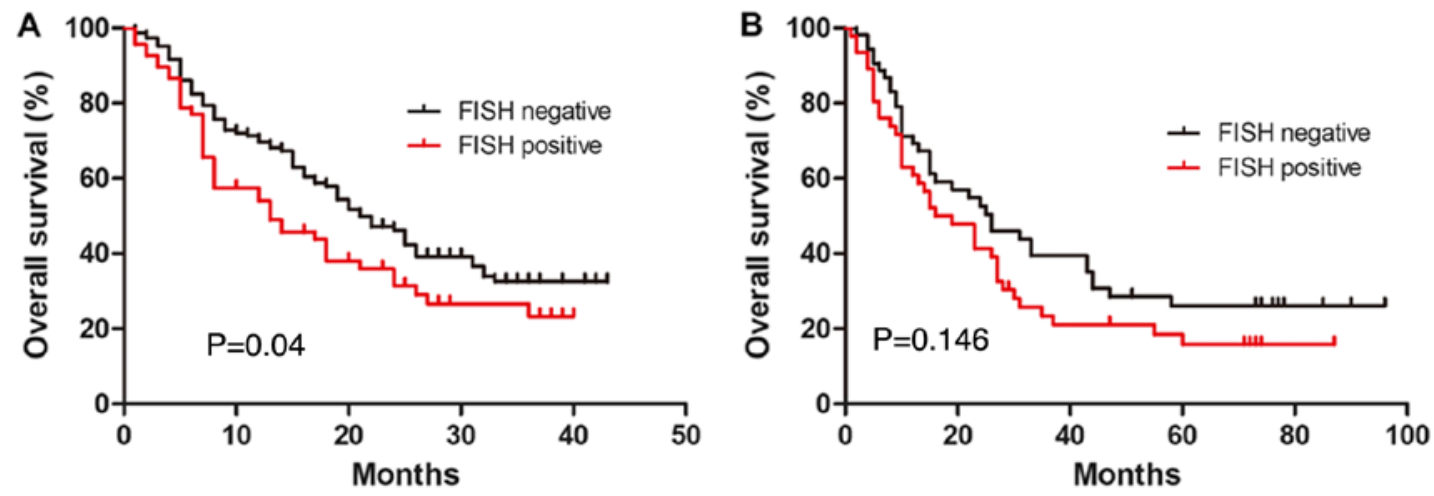

Figure 3. Kaplan-Meier survival analysis of patients with esophageal squamous cell carcinoma with tumor protein 53 gene deletion. (A) Multi-ethnic group. (B) Tissue microarray. FISH, fluorescence in situ hybridization.

mutation and detection of $\mathrm{p} 53$ protein accumulation by IHC can indirectly evaluate TP53 gene mutation. However, IHC may miss TP53 gene deletion (20). DNA FISH can directly detect the loss of the TP53 gene locus, which is one of the main molecular features of the tumor suppressor gene variation and an important marker for the transformation of some normal cells. 
Table IV.Association between p53 gene deletion and clinicopathological characteristics of patients with ESCC (tissue microarray).

\begin{tabular}{|c|c|c|c|c|c|}
\hline \multirow[b]{2}{*}{ Characteristics } & \multirow[b]{2}{*}{$\mathrm{N}$} & \multicolumn{2}{|c|}{ p53 FISH } & \multirow[b]{2}{*}{$\chi^{2}$} & \multirow[b]{2}{*}{ P-value } \\
\hline & & Positive (\%) & Negative (\%) & & \\
\hline Specimen & & & & 56.31 & $<0.001$ \\
\hline Adjacent normal tissue & 97 & $2(2.1)$ & $95(97.9)$ & & \\
\hline ESCC & 117 & $56(47.9)$ & $61(52.1)$ & & \\
\hline Sex & & & & 0.484 & 0.487 \\
\hline Male & 87 & $40(46)$ & $47(54)$ & & \\
\hline Female & 30 & $16(53.3)$ & $14(46.7)$ & & \\
\hline Age, years & & & & 1.506 & 0.22 \\
\hline$\leq 60$ & 40 & $16(40)$ & $24(60)$ & & \\
\hline$>60$ & 77 & $40(51.9)$ & $37(48.1)$ & & \\
\hline $\mathrm{N}$ classification & & & & 8.484 & 0.003 \\
\hline No & 54 & $18(33.3)$ & $36(66.7)$ & & \\
\hline Yes & 63 & $38(60.3)$ & $25(39.7)$ & & \\
\hline T classification & & & & 0.008 & 0.557 \\
\hline T1-T2 & 23 & $11(47.8)$ & $12(52.2)$ & & \\
\hline T3-T4 & 94 & $45(47.9)$ & $49(52.1)$ & & \\
\hline TNM stage & & & & 6.353 & 0.01 \\
\hline I-II & 56 & $20(35.7)$ & $36(64.3)$ & & \\
\hline III-IV & 61 & $36(41.0)$ & $25(59.0)$ & & \\
\hline Differentiation & & & & 1.184 & 0.194 \\
\hline Good & 26 & $10(38.5)$ & $16(61.5)$ & & \\
\hline Moderate-poor & 91 & $46(50.5)$ & $45(49.5)$ & & \\
\hline
\end{tabular}

ESCC, esophageal squamous cell carcinoma; FISH, fluorescence in situ hybridization.

Table V. Univariate and multivariate analysis of overall survival in patients with esophageal squamous cell carcinoma.

\begin{tabular}{|c|c|c|c|c|}
\hline \multirow[b]{2}{*}{ Variables } & \multicolumn{2}{|c|}{ Univariate analysis } & \multicolumn{2}{|c|}{ Multivariate analysis } \\
\hline & $\mathrm{HR}(95 \% \mathrm{CI})$ & P-value & $\mathrm{HR}(95 \% \mathrm{CI})$ & P-value \\
\hline Sex, female vs. male & $1.271(0.843-1.918)$ & 0.252 & & \\
\hline Age,$\leq 60$ vs. $>60$ years & $1.365(0.955-1.952)$ & 0.087 & & \\
\hline T classification, T1-T2 vs. T3-T4 & $1.335(0.926-1.925)$ & 0.121 & & \\
\hline $\mathrm{N}$ classification, negative vs. positive & $2.336(1.630-3.348)$ & $<0.001$ & $0.500(0.341-0.733)$ & $<0.001$ \\
\hline Differentiation, good vs. moderate-poor & $1.229(0.964-1.569)$ & 0.097 & & \\
\hline Tumor size, $<4 \mathrm{~cm}$ vs. $\geq 4 \mathrm{~cm}$ & $1.116(0.785-1.587)$ & 0.54 & & \\
\hline Vascular invasion, negative vs. positive & $2.386(1.585-3.593)$ & $<0.001$ & $0.563(0.363-0.874)$ & 0.01 \\
\hline p53 FISH, negative vs. positive & $1.457(1.009-2.105)$ & 0.04 & $0.863(0.589-1.265)$ & 0.45 \\
\hline p54 IHC, negative vs. positive & $1.122(0.785-1.603)$ & 0.527 & & \\
\hline
\end{tabular}

FISH, fluorescence in situ hybridization; IHC, immunohistochemistry; HR, hazard ratio.

The present study demonstrated that the positive rates of p53 protein expression in ESCC of in two groups, a multi-ethnic group and a TMA group, were 54.5 and $58.1 \%$, respectively. It was also demonstrated that p53 protein expression was associated with tumor differentiation and depth of invasion, which indicated that the TP53 mutation was not only related to the occurrence of ESCC, but also to prognostic factors such as malignant phenotype, invasion and metastasis, which were indirectly related to adverse prognosis. However, there was no significant association between p53 protein expression and other clinical factors, such as lymph node metastasis, TNM stage and overall survival, which was consistent with previous 
Table VI. Univariate and multivariate analysis of overall survival in patients with esophageal squamous cell carcinoma (tissue microarray).

\begin{tabular}{|c|c|c|c|c|}
\hline \multirow[b]{2}{*}{ Variables } & \multicolumn{2}{|c|}{ Univariate analysis } & \multicolumn{2}{|c|}{ Multivariate analysis } \\
\hline & $\mathrm{HR}(95 \% \mathrm{CI})$ & P-value & $\mathrm{HR}(95 \% \mathrm{CI})$ & P-value \\
\hline Sex, female vs. male & $1.842(1.043-3.254)$ & 0.035 & $0.728(0.446-1.187)$ & 0.203 \\
\hline Age,$\leq 60$ vs. $>60$ years & $0.990(0.615-1.594)$ & 0.967 & & \\
\hline $\mathrm{T}$ classification, T1-T2 vs. T3-T4 & $0.339(0.155-0.745)$ & 0.007 & $1.925(1.073-3.451)$ & 0.028 \\
\hline $\mathrm{N}$ classification, negative vs. positive & $0.544(0.340-0.871)$ & 0.011 & $0.449(0.201-1.007)$ & 0.052 \\
\hline Differentiation, good vs. moderate-poor & $0.295(0.150-0.580)$ & $<0.001$ & $0.324(0.162-0.646)$ & 0.001 \\
\hline p53 FISH, negative vs. positive & $0.701(0.445-1.105)$ & 0.126 & & \\
\hline p53 IHC, negative vs. positive & $1.117(0.705-1.770)$ & 0.638 & & \\
\hline
\end{tabular}

FISH, fluorescence in situ hybridization; IHC, immunohistochemistry; HR, hazard ratio.

Table VII. Concordance between the results of IHC and FISH in esophageal squamous cell carcinoma.

A, Multi ethnic group

\begin{tabular}{lccc}
\hline & \multicolumn{2}{c}{ p53 FISH } & \\
\cline { 2 - 3 } p53 IHC & Positive, \% & Negative, \% & $\begin{array}{c}\text { Concordance } \\
\text { rate, \% }\end{array}$ \\
\hline Negative & 29 & 90 & 75.6 \\
Positive & 39 & 56 & 41.1 \\
Total & 68 & 146 & 60.3 \\
\hline
\end{tabular}

$\mathrm{B}$, Tissue microarray

\begin{tabular}{lccc}
\hline & \multicolumn{2}{c}{ p53 FISH } & \\
\cline { 2 - 3 } p53 IHC & Positive, \% & Negative, \% & $\begin{array}{c}\text { Concordance } \\
\text { rate, \% }\end{array}$ \\
\hline Negative & 15 & 34 & 69.4 \\
Positive & 41 & 27 & 60.3 \\
Total & 56 & 61 & 64.1 \\
\hline
\end{tabular}

FISH, fluorescence in situ hybridization; IHC, immunohistochemistry.

studies by Taghavi et al (19) and Yen et al (28). By contrast, previous studies have reported that mutated $\mathrm{p} 53$ protein could promote the invasion and metastasis of tumors and affect the prognosis of patients with $\operatorname{ESCC}(15,29,30)$. These conflicting results could be due to different patient selection processes, differences in the types of antibodies used and cut-ff values for p53 expression used in the different studies $(18,31)$.

The present study also detected p53 protein expression in Han, Uygur and Kazakh ethnic groups from Xinjiang, and identified that there were no significant differences in p53 protein expression among the three ethnicities, indicating that p53 protein expression was similar in patients with ESCC from different ethnic groups. In addition, the present results demonstrated that the expression of $\mathrm{p} 53$ protein was signifi- cantly associated with sex in the multi-ethnic group. However, the majority of previous studies on p53 suggested that there were no associations with sex $(15,19,28)$. It was hypothesized that the present results could be an incidental anomaly due to the small sample size. The possible association between p53 and sex may be further confirmed by a larger sample size in future studies.

Moreover, the present study also detected TP53 gene deletion. TP53 gene deletion rates were 31.8 and $47.9 \%$ in the tumor tissues of the multi-ethnic and the TMA groups, respectively. In addition, TP53 gene deletion was also related to prognostic factors such as tumor differentiation and lymph node metastasis. In a previous study of p53 IHC and loss of heterozygosity $(\mathrm{LOH})$ analysis with similar experimental conditions, including 94 resected ESCC samples, the TP53 $\mathrm{LOH}$ rate was $67.5 \%$, but it was not associated with the malignant phenotype of ESCC (22). In our previous study, FISH was used to detect TP53 gene deletion in patients with ESCC of Kazakh background, which suggested that TP53 gene deletion was related to tumor differentiation and lymph node metastasis (32). In the present study, additional ethnicities and samples were included, and TP53 gene deletion was demonstrated to be more common in patients with poor differentiation, lymph node metastasis and vascular invasion at advanced stages, which was consistent with our previous study, suggesting that the altered TP53 may play an important role in predicting the prognosis of ESCC. In addition, there was a significant association between TP53 gene deletion and overall survival in multi-ethnic groups. Although there was no significant association between TP53 gene deletion and overall survival in the TMA group, patients with TP53 gene deletion displayed a tendency towards worse prognosis, compared with those without the deletion, which was consistent with the result of multi-ethnic groups. Overall, the present results suggested that TP53 gene deletion was associated with poor prognosis and may be a potential and effective prognostic indicator of ESCC.

The expression rates of $\mathrm{p} 53$ protein were 54.5 and $58.1 \%$, and the deletion rates of the TP53 gene were 31.8 and $47.9 \%$ in the two groups, respectively. The total concordance rates of FISH and IHC for detecting TP53 gene abnormality were 60.3 
Table VIII. p53 abnormalities detected by FISH and IHC at different histological stages.

\section{A, FISH}

\begin{tabular}{|c|c|c|c|c|}
\hline \multirow[b]{2}{*}{ Histology } & \multirow[b]{2}{*}{$\mathrm{n}$} & \multicolumn{2}{|c|}{ p53 } & \multirow[b]{2}{*}{ P-value } \\
\hline & & Positive $(\%)$ & Negative & \\
\hline Normal esophageal mucosa & 3 & 0 & 3 & \\
\hline Adjacent normal tissue & 97 & $2(2.1)$ & 95 & \\
\hline Precancerous lesion & 13 & $4(30.8)$ & 9 & $<0.001$ \\
\hline ESCC tissue & 117 & $56(47.9)$ & 61 & \\
\hline Metastatic lesion & 9 & $8(88.9)$ & 1 & \\
\hline
\end{tabular}

$\mathrm{B}, \mathrm{IHC}$

\begin{tabular}{|c|c|c|c|c|}
\hline \multirow[b]{2}{*}{ Histology } & \multirow[b]{2}{*}{$\mathrm{n}$} & \multicolumn{2}{|c|}{ p53 } & \multirow[b]{2}{*}{ P-value } \\
\hline & & Positive (\%) & Negative & \\
\hline Normal esophageal mucosa & 3 & 03 & & \\
\hline Adjacent normal tissue & 97 & $11(11.3)$ & 86 & \\
\hline Precancerous lesion & 13 & $6(46.2)$ & 7 & $<0.001$ \\
\hline ESCC tissue & 117 & $68(58.1)$ & 49 & \\
\hline Metastatic lesion & 9 & $7(77.8)$ & 2 & \\
\hline
\end{tabular}

C, FISH and IHC

\begin{tabular}{lrrrr}
\hline & & \multicolumn{2}{c}{$\mathrm{p} 53$} \\
\cline { 3 - 5 } Histology & $\mathrm{n}$ & Positive (\%) & Negative \\
\hline Normal esophageal mucosa & 3 & 0 & 3 & 84 \\
Adjacent normal tissue & 97 & $13(13.4)$ & 4 & 34 \\
Precancerous lesion & 13 & $9(69.2)$ & 1 \\
ESCC tissue & 117 & $8(88.9)$ & 001 \\
Metastatic lesion & 9 & $83(70.9)$ & \\
\hline
\end{tabular}

ESCC, esophageal squamous cell carcinoma; FISH, fluorescence in situ hybridization; IHC, immunohistochemistry.

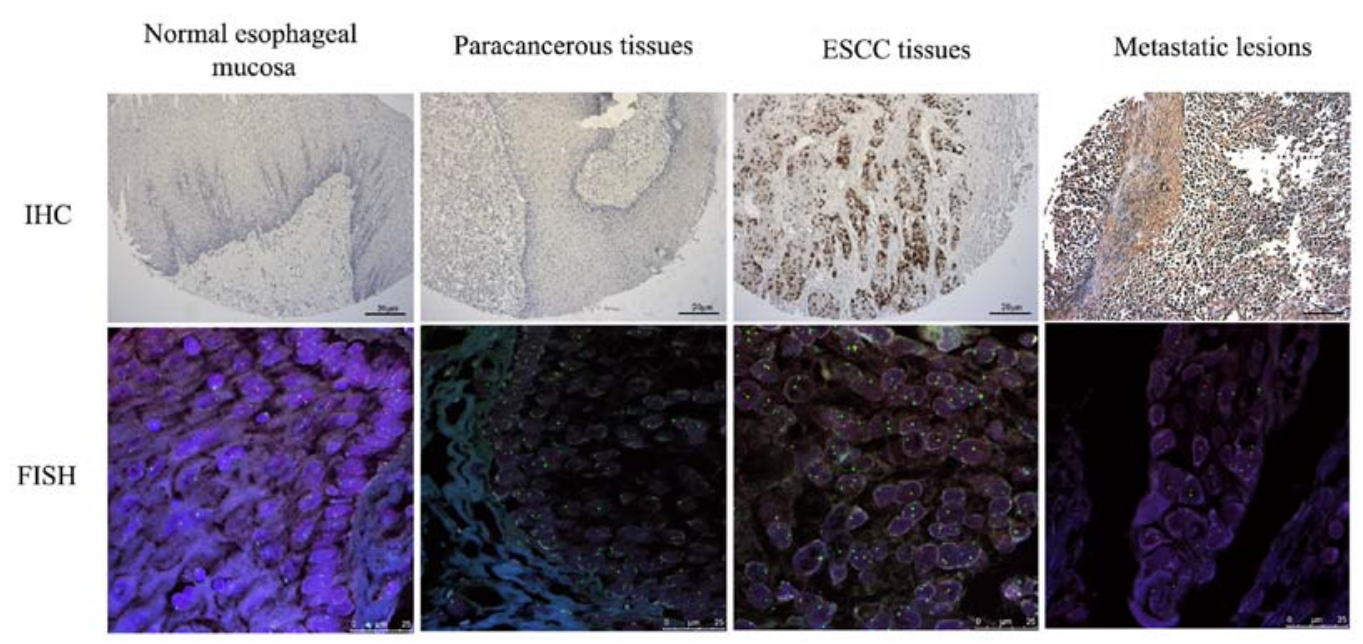

Figure 4. Tumor protein 53 protein expression and gene deletion status at different histological stages of ESCC. Magnification, IHC x10, FISH x100. ESCC, esophageal squamous cell carcinoma; FISH, fluorescence in situ hybridization; IHC, immunohistochemistry. 
and $64.1 \%$, respectively. When both methods were used simultaneously, the detection rate of TP53 gene abnormalities was significantly increased. A previous study by Graesslin et al (33) reported that there was no significant association between TP53 gene deletion and $\mathrm{p} 53$ protein expression in endometrial cancer, and there was no significant association between TP53 gene deletion and clinical prognostic factors. Therefore, FISH was not recommended for the routine detection of the TP53 gene in endometrial cancer (33). However, the present results support the combination of FISH and IHC in assessing TP53 abnormalities in ESCC. Although FISH allows objective quantification of results by counting intranuclear signals, there are some disadvantages to this method, such as the influence of non-tumor cells on the results. However, the present study suggested that IHC combined with FISH could overcome this limitation.

In addition, the present study also detected TP53 abnormalities in different stages of ESCC and found that TP53 gene deletion and protein expression increased with the progression of ESCC. In a study of Barrett's esophagus, Davelaar et al (34) reported that the positive rates of TP53 FISH and IHC increased with the progression of the disease, and the combined use of FISH and IHC technology could significantly improve the detection rate of TP53 gene abnormalities at different stages of the disease, which is similar to the present results in ESCC. These results also indicated that TP53 gene abnormalities are not only an early event of esophageal cancer, but also play an important role in tumor progression.

However, the sample size was relatively small and only one core of tumor tissue for each patient was included in TMA, which may account for the difference in the results observed between the TMA and the multi-ethnic group. Therefore, verification of the results with TMA, including larger sample size and more tumor cores is required in subsequent studies.

In conclusion, the present results demonstrated that the TP53 gene mutation played an important role in the occurrence and development of ESCC. The factors affecting p53 overexpression are complex, and TP53 gene deletion is one of the most important. These results suggested that FISH could be used as an additional method in the diagnosis of ESCC, especially when IHC results are negative. The application of FISH could increase the accuracy of chromosome karyotype determination, improve the detection efficiency of TP53 gene abnormalities in ESCC, and help accurately evaluate the malignancy and prognosis of esophageal cancer.

\section{Acknowledgements}

Not applicable.

\section{Funding}

The present study was funded by The National Natural Science Foundation (grant no. 81360305).

\section{Availability of data and materials}

The datasets used and/or analyzed during the current study are available from the corresponding author on reasonable request.

\section{Authors' contributions}

MN and EA was mainly responsible for designing and performing the experiments. JA and AA was mainly responsible for analyzing and interpreting the data, and performed statistical analysis. LZ and IS provided the study materials and revised the manuscript critically, and also guided the research design and experiment. AT was mainly responsible for drafting the manuscript and collecting clinical data, including clinicopathological data and patient follow-up data. RC and ZH helped with performing the experiments. All authors read and approved the final manuscript.

\section{Ethics approval and consent to participate}

All experiments were approved by The Ethics Committee of The First Affiliated Hospital of Xinjiang Medical University, and written informed consent was obtained from all participants.

\section{Patient consent for publication}

Not applicable.

\section{Competing interests}

The authors declare that they have no competing interests.

\section{References}

1. Napier KJ, Scheerer M and Misra S: Esophageal cancer: A review of epidemiology, pathogenesis, staging workup and treatment modalities. World J Gastrointest Oncol 6: 112-120, 2014.

2. Bray F, Ferlay J, Soerjomataram I, Siegel RL, Torre LA and Jemal A: Global cancer statistics 2018: GLOBOCAN estimates of incidence and mortality worldwide for 36 cancers in 185 countries. CA Cancer J Clin 68: 394-424, 2018.

3. Siegel R, Ma J, Zou Z and Jemal A: Cancer statistics, 2014. CA Cancer J Clin 64: 9-29, 2014.

4. Zeng H, Zheng R, Zhang S, Zuo T, Xia C, Zou X and Chen W: Esophageal cancer statistics in China, 2011: Estimates based on 177 cancer registries. Thorac Cancer 7: 232-237, 2016.

5. Chen W, Zheng R, Baade PD, Zhang S, Zeng H, Bray F, Jemal A, Yu XQ and He J: Cancer statistics in China, 2015. CA Cancer J Clin 66: 115-132, 2016.

6. Lin Y, Totsuka Y, He Y, Kikuchi S, Qiao Y, Ueda J, Wei W, Inoue $\mathrm{M}$ and Tanaka $\mathrm{H}$ : Epidemiology of esophageal cancer in Japan and China. J Epidemiol 23: 233-242, 2013.

7. Pennathur A, Gibson MK, Jobe BA and Luketich JD: Oesophageal carcinoma. Lancet 381: 400-412, 2013.

8. Soussi T: The p53 pathway and human cancer. Brit J Surg 92: 1331-1332, 2005.

9. Vousden KH and Lane DP: p53 in health and disease. Nat Rev Mol Cell Biol 8: 275-283, 2007.

10. da Silva GN, Evangelista AF, Magalhães DA, Macedo C, Búfalo MC, Sakamoto-Hojo ET, Passos GA and Salvadori DM: Expression of genes related to apoptosis, cell cycle and signaling pathways are independent of TP53 status in urinary bladder cancer cells. Mol Biol Rep 38: 4159-4170, 2011.

11. Cardin R, Piciocchi M, Tieppo C, Maddalo G, Zaninotto G, Mescoli C, Rugge M and Farinati F: Oxidative DNA damage in Barrett mucosa: Correlation with telomeric dysfunction and p53 mutation. Ann Surg Oncol 20 (Suppl 3): S583-S589, 2013.

12. Di Agostino S, Strano S and Blandino G: Gender, mutant $\mathrm{p} 53$ and PML: A growing 'affaire' in tumor suppression and oncogenesis. Cell Cycle 12: 1824-1825, 2013.

13. Greenblatt MS, Bennett WP, Hollstein M and Harris CC: Mutations in the p53 tumor suppressor gene: Clues to cancer etiology and molecular pathogenesis. Cancer Res 54: 4855-4878, 1994.

14. Song Y, Li L, Ou Y, Gao Z, Li E, Li X, Zhang W, Wang J, Xu L, Zhou Y, et al: Identification of genomic alterations in oesophageal squamous cell cancer. Nature 509: 91-95, 2014. 
15. Huang K, Chen L, Zhang J, Wu Z, Lan L, Wang L, Lu B and Liu Y: Elevated p53 expression levels correlate with tumor progression and poor prognosis in patients exhibiting esophageal squamous cell carcinoma. Oncol Lett 8: 1441-1446, 2014.

16. Okumura H, Kita Y, Yokomakura N, Uchikado Y, Setoyama T, Sakurai H, Omoto I, Matsumoto M, Owaki T, Ishigami S and Natsugoe S: Nuclear expression of 14-3-3 sigma is related to prognosis in patients with esophageal squamous cell carcinoma. Anticancer Res 30: 5175-5179, 2010.

17. Zhao Z, Wang P, Gao Y and He J: The high expression instead of mutation of p53 is predictive of overall survival in patients with esophageal squamous-cell carcinoma: A meta-analysis. Cancer Med 6: 54-66, 2017

18. Murata A, Baba Y, Watanabe M, Shigaki H, Miyake K, Karashima R, Imamura Y, Ida S, Ishimoto T, Iwagami S, et al: p53 immunohistochemical expression and patient prognosis in esophageal squamous cell carcinoma. Med Oncol 30: 728, 2013.

19. Taghavi N, Biramijamal F, Sotoudeh M, Moaven O, Khademi H, Abbaszadegan MR and Malekzadeh R: Association of p53/p21 expression with cigarette smoking and prognosis in esophageal squamous cell carcinoma patients. World J Gastroenterol 16: 4958-4967, 2010.

20. Nenutil R, Smardova J, Pavlova S, Hanzelkova Z, Muller P, Fabian P, Hrstka R, Janotova P, Radina M, Lane DP, et al: Discriminating functional and non-functional p53 in human tumours by $\mathrm{p} 53$ and MDM2 immunohistochemistry. J Pathol 207: 251-259, 2005

21. Halling KC and Kipp BR: Fluorescence in situ hybridization in diagnostic cytology. Hum Pathol 38: 1137-1144, 2007.

22. Tafe LJ, Allen SF, Steinmetz HB, Dokus BA, Cook LJ, Marotti JD and Tsongalis GJ: Automated processing of fluorescence in-situ hybridization slides for HER2 testing in breast and gastro-esophageal carcinomas. Exp Mol Pathol 97: 116-119, 2014.

23. Egashira A, Morita M, Yoshida R, Saeki H, Oki E, Sadanaga N, Kakeji Y, Tsujitani S and Maehara Y: Loss of p53 in esophageal squamous cell carcinoma and the correlation with survival: Analyses of gene mutations, protein expression, and loss of heterozygosity in Japanese patients. J Surg Oncol 104: 169-175, 2011.

24. Bellini MF, Cadamuro AC, Succi M, Proenca MA and Silva AE: Alterations of the TP53 gene in gastric and esophageal carcinogenesis. J Biomed Biotechnol 2012: 891961, 2012.

25. Edge SB and Compton CC: The American joint committee on cancer: The 7th edition of the AJCC cancer staging manual and the future of TNM. Ann Surg Oncol 17: 1471-1474, 2010.
26. Fagundes RB, Melo CR, Pütten AC, Moreira LF and de Barros SG: p53 immunoexpression: An aid to conventional methods in the screening of precursor lesions of squamous esophageal cancer in patients at high-risk? Cancer Detect Prev 29: 227-232, 2005

27. Muller PA and Vousden KH: p53 mutations in cancer. Nat Cell Biol 15: 2-8, 2013.

28. Yen CC, Tsao YP, Chen PC, Wu YC, Liu JH, Pan CC, Liu CY, Tzeng $\mathrm{CH}$, Chen PM, Chen YJ, et al: PML protein as a prognostic molecular marker for patients with esophageal squamous cell carcinomas receiving primary surgery. J Surg Oncol 103: 761-767, 2011

29. Wang L, Yu X, Li J, Zhang Z, Hou J and Li F: Prognostic significance of p53 expression in patients with esophageal cancer: A meta-analysis. BMC Cancer 16: 373, 2016.

30. Melling N, Norrenbrock S, Kluth M, Simon R, Hube-Magg C, Steurer S, Hinsch A, Burandt E, Jacobsen F, Wilczak W, et al: p53 overexpression is a prognosticator of poor outcome in esophageal cancer. Oncol Lett 17: 3826-3834, 2019.

31. Yamamoto S, Yashima K, Kawata S, Hosoda K, Tamoto A, Ikebuchi Y, Matsumoto K, Kawaguchi K, Harada K, Murawaki Y and Isomoto H: Frequent aberrant p53 and Fhit expression in endoscopically resected superficial hypopharyngeal cancer and esophageal cancer. Oncol Lett 14: 587-592, 2017.

32. Niyaz M, Turghun A, Ping ZH, Zhu Z, Sheyhedin I, Ren C and Awut I: TP53 gene deletion in esophageal cancer tissues of patients and its clinical significance. Mol Med Rep 7: 122-126, 2013.

33. Graesslin O, Chantot-Bastaraud S, Lorenzato M, Birembaut P, Quéreux C and Daraï E: Fluorescence in situ hybridization and immunohistochemical analysis of p53 expression in endometrial cancer: Prognostic value and relation to ploidy. Ann Surg Oncol 15: 484-492, 2008.

34. Davelaar AL, Calpe S, Lau L, Timmer MR, Visser M, Ten Kate FJ, Parikh KB, Meijer SL, Bergman JJ, Fockens P and Krishnadath KK: Aberrant TP53 detected by combining immunohistochemistry and DNA-FISH improves Barrett's esophagus progression prediction: A prospective follow-up study. Genes Chromosomes Cancer 54: 82-90, 2015. International (CC BY-NC-ND 4.0) License. 